\title{
List of presentation at Joint Symposium on Biology of Tidal Flats 2009 in Suncheon, Korea
}

\section{Plenary lecture, Ronald M. THOM (USA)}

Restoration of Estuarine and Coastal Nearshore Ecosystems in the United States, with Special Reference to Pacific Northwest Region

Hiroshi MUKAI and Kyoko HATA (Japan)

Tidal flat reclamation plans and their effects on water quality, seagrass beds and clam productivity in Mikawa Bay

Il-Hoi KIM (Korea)

Copepoda symbiotic with benthic invertebrates from Korea

Haruhiko TOYOHARA, Kentaro SAKAMOTO (Japan)

Cellulose digestion by Japanese brackish bivalves Corbicula japonica

Jong-Geel JE (Korea)

Why does the mudskipper, Boleophthalmus pectinirostris, distribute only here?: a conservation recommendation

Plenary lecture, Hiroaki TSUTSUMI (Japan)

Ecosystem crisis in the innermost areas of Ariake Bay after closure of the gates of the dike in Isahaya Bay

Takao SUZUKI, Miki SASAKI (Japan)

Civil procedure for researching benthic invertebrate animals inhabit tidal flat

Gi-Chul YI, Jae-One LEE, Yong-Suk KIM (Korea)

Suggesting the method to make the 3D wetland list from Airborne LIDAR Data

N. HASEGAWA, J. HIGANO, Y. FUJIOKA, Y. ISHIHI, T. MIZUNO, T. MARUYAMA, K. HODOKAWA, T. SAKAMI, H. SAITO, R. NANBU, H. KUWAHARA (Japan)

Relationship between the juvenile Manila clam Ruditapes philippinarum and the Nori-culture nets on tidal flats

Tomohiro KOMORITA, Rumiko KAJIHARA, Hiroaki TSUTSUMI Seiichiro SHIBANUMA, Toshiro YAMADA, and Shigeru MONTANI (Japan)

Trophic linkage between biological activity of bivalve (Ruditapes philippinarum) and photosynthetic activity of microphytobenthos in a subarctic lagoon.

\section{Bon Joo KOO, Sang-Ho SHIN and Jong Geel JE (Korea)}

Spatial patterns of benthic macrofauna in relation to environmental variables in estuarine tidal flats, the west coast of Korea: Application of satellite image analyses for intertidal habitat classification

Soon-Mo AN, Sorcha Ní Longphuirt, Jae-Hyun LIM, Aude LEYNAERT, Pascal CLAQUIN, Eun-Jung CHOY and Chang-Keun KANG (Korea)

Temporal evolution of porewater concentrations of dissolved inorganic nitrogen (DIN) and its implications on intertidal microphytobenthos

Plenary leclure, J-P DUCROTOY (UK) and Dr. P. GALICHON (France)

Ecological restoration of tidal estuaries in Europe: a strategy for adapting to the climate change

Hiroaki TOSUJI and Masanori SATO (Japan)

Genetic evidence for parapatric differentiation of two forms in the brackish-water nereidid polychaete Hediste atoka

Dong-Sung KIM, Won-Gi MIN, Hyun-Soo RHO, Tea-Wook KANG and Heung-Sik PARK (Korea)

Effect of oil spill on meiobenthic community in tidal zone of the Yellow Sea, Korea.

Shin'ichi SATO, Hiroyoshi YAMSHITA, Hiroshi TORII and Kyung-Won KIM (Japan)

Geographical distributions of the endemic species and their related species around the tidal flats in Korea and Japan 


\section{Kenji OKOSHI (Japan)}

The clam-eating alien snail Euspira fortunei and its impact for clam culture in Japan

\section{Chang-Keun KANG, Hyun Je PARK, Eun Jung CHOY, Kun-Seop LEE (Korea)}

Stable isotopes and fatty acid analyses reveal trophic links among coastal habitats in a seagrass-dominated macrotidal embayment system

Jae-Won YOO, Chang-Gun LEE, Chang-Soo KIM, Mi-Ra PARK, Kon- Tak YOON, In-Seo HWANG, Hoe-In JUNG and Jae-Sang HONG (Korea)

Rare species of tidal flat macrobenthic communities in Korea

Plenary lecture, Prof. Masanori SATO (Japan)

The peculiar fauna of muddy tidal flats in eastern Asia, and its anthropogenic decline, with special reference to estuarine polychaetes

\section{Plenary lecture, Wenshan HE and Prof. Jianjian LU (China)}

Wetland Restoration Practices at the Yangtze Estuary

\section{Eunkyung LEE, Sungyun LEE, Jaeweon CHO (Korea)}

The occurrence of selected pharmaceutical compounds in estuarine wetland influenced with wastewater effluent

\section{[Poster presentation]}

Keun-Hyung CHOI, Sung-Mi LEE, Sang-Min LIM and Gyung-Soo PARK (Korea) Benthic habitat quality changes as measured by macrofauna community in a tidal flat on the west coast of yellow Sea

\section{Ohnmar MYINT and Makoto TSUCHIYA (Japan)}

Ecological role of effect by burrow-dwelling Gobiidae fish (Periophthalmus argentilineatus) on the organic matter and nutrient status in Manko Wetland, Okinawa Island, Japan

\section{Sung-Mi LEE, Gyung-Soo PARK, Sang-Min LIM and Keun-Hyung CHOI (Korea)}

Habitat susceptibility to desalination on the west coast of Korea

\section{Shoko OZEKI, Kunio KOHATA, Yasuo NAKAMURA, Takehiko HIWATARI, Sigeaki KOJIMA (Japan)}

Influence of salinity on filtration activity of the brackish water clam Corbicula japonica (Bivalvia: Corbiculidae)

Sang-Min LIM, Keun-Hyung CHOI, Sung-Mi LEE and Gyung-Soo PARK (Korea)

Recruitment of benthic macroinfauna in three different types of microcosms

\section{Hiroshi TORII, Masami HAMAGUCHI and Shin'ichi SATO (Japan)}

The comparison of shell morphology and genetic relationship between Meretrix lusoria and M. petechialis in Japan and South Korea

\section{Bon-Joo KOO, Sang-Ho SHIN and Chul-Hwan KOH (Korea)}

Effects of macrofaunal bioturbation on oxygen diffusion from sediment-water interface and on the increase in oxic sediment volume within tidal sediments

\section{Yoshihiro B. AKIYAMA, Hajime SAITO, Ryogen NANBU, Yoshio TANAKA and Hisami KUWAHARA (Japan)} Attempt to analyze the factor regulating the spatial distribution of short-neck clam Ruditapes philippinarum on a sandy tidal flat

\section{Bon-Joo KOO, Jung-Ho HYUN, Chul-Hwan KOH (Korea)}

Introduction of a complex burrow system of the mud shrimp Laomedia astacina and its geochemical implications within the tidal sediments 
Yukio SASAGO and Atsushi TANIMURA (Japan)

Seasonal distribution patterns of sandhopper, Sinorchestia nipponensis on a sandy beach in Ise Bay, Central Japan: relationship to environmental variables.

\section{Jin-Woo CHOI and Jin-Young SEO (Korea)}

Community structures of macrozoobenthos inhabit on the artificial and natural tidal flat of Masan Bay, Korea

Ikue SEKIGUCHI, Rumiko KAJIHARA, Natsumi ISHIMARU, Seiichiro SHIBANUMA, Toshiro YAMADA, Shigeru MONTANI (Japan)

Impact of migratory birds (Whooper Swan) during the winter on the process of material cycle in sub-arctic lagoon, Hichirippu-Numa, Hokkaido, Japan

\section{Ok-Hwan YU, Hyung-Gon LEE and Jae-Hac LEE (Korea)}

Variation of an intertidal macrobenthic community along an artificial structure

\section{Ryo UMEHARA, Hiroaki TSUTSUMI, Tohru TAKAHASHI (Japan)}

Blooming of blue-green algae in the reservoir of Isahaya reclaimed land and its influence on aquatic animals

\section{Sook-Yang KIM, Kyu-Kui JUNG and Hi-Dong JOUNG (Korea)}

Characteristics of algal pigment distributions in the tidal flat of Suncheon Bay

\section{Takafumi TANOUE and Hiroaki TSUTSUMI (Japan)}

Population dynamics of three dominant edible clams, Ruditapes philippinarum, Meretrix lusoria and Mactra veneriformis on Midori River Tidal Flats in Kumamoto, Kyushu, Japan

\section{Hong-Shik OH, Byoung-Soo KIM and Si-Wan LEE (Korea)}

Current status of black-faced spoonbills wintering in Jeju Island and Ways of protecting their wintering sites dependent on sources of potential prey

Rumiko KAJIHARA, Natsumi ISHIMARU, Ikue SEKIGUCHI, Yuki MANAGAKI, Hirotaka TAOKA, Seiichiro SHIBANUMA, Toshiro YAMADA and Shigeru MONTANI (Japan)

Evaluation of river influence on primary producers and consumers in a subarctic lagoon, Hokkaido, Japan

\section{Si-Wan LEE, Tae Han KANG and Han-Soo LEE (Korea)}

Feeding ecology of Dunlins (Calidris alpina) in relation to their preys on Yeochari Tidal Flat in the Southern Ganghwa Island of South Korea

Koji SEIKE (Japan)

Behavioral ecology of an infaunal polychaete worm Euzonus sp. inferred from their feeding traces

Jae-Sang HONG, B.M. CHOI, A. KUBO and M. SATO (Korea)

Redescription of a giant mud worm Paraleonnates uschakovi Khlebovich and Wu, 1962 (Nereididae: Polychaeta: Annelida) with special reference to its junior synonym of Periserrula leucophryna Paik, 1977)

Nobyuki OKANIWA, Tsuzumi MIYAJI and Takenori SASAKI, Kazushige TANABE (Japan)

Shell growth and reproductive cycle of the Mediterranean mussel Mytilus galloprovincialis in Tokyo Bay, Japan: relationship with environmental conditions

\section{Sang-Pil YOON and Jae-Sang HONG (Korea)}

Spatio-temporal changes of macrobenthic community structure in different habitats around Galsa delta of Gwangyang Bay, Korea

Tsuzumi MIYAJI, Kazushige TANABE, Bernd R. SCHNE (Japan)

Environmental controls on daily shell growth of Phacosoma japonicum (Bivalvia: Veneridae) from Japan 


\section{Tae-Wan KIM and Yang-Ki CHO (Korea)}

Variability of the sediment temperature and its prediction in tidal flat

\section{Taeko KIMURA and Shoichi KIMURA (Japan)}

Long-term observation of growth and spatial distribution of salt marsh snail Ellobium chinense on the Shiokawa Tidal Flat, central Japan, by mark-recapture method

\section{Jae-Sam YANG and Soh-Young KIM (Korea)}

Variations of macro-benthic communities in Saemangeum Salt-Lake due to the dike construction

Kanako TSUCHIYA, Young-Hwa PARK, Kentaro SAKAMOTO and Haruhiko TOYOHARA (Japan)

Role of meiobenthos in the cellulose decomposition in the estuary

\section{Eun Jung CHOY, Pierre RICHARD, Kyung-Ryul KIM and Chang-Keun KANG (Korea)}

Quantifying the trophic base for benthic secondary production in a controlled estuarine system using stable $\mathrm{C}$ and $\mathrm{N}$ isotopes

\section{Takashi NOJIMA and Yasuhisa HENMI (Japan)}

Female choice in the intertidal dotillid crab Ilyoplax pusilla

\section{Won-Gi MIN, Dongsung KIM and Jae-Sang HONG (Korea)}

Changes and movement of meiobenthic community associated with artificial low- crested facility at Iwon tidal flat in west coast of Korea

Takatoshi NIIYAMA, Kentaro SAKAMOTO, Kanako TSUCHIYA and Haruhiko TOYOHARA (Japan) Comparative and ecological study of cellulase and hemicellulases activities of aquatic invertebrates

\section{Hyun-Sig LIM (Korea)}

Spatial distribution of macrobenthic assemblages in Suncheon (Yeoja) Bay, Korea

\section{Masato OWADA, Shin'ichi SATO, Hiroyoshi YAMASHITA, Jae-Sang HONG and Jørgen L TZEN (Japan)} Comparison of shell morphology and DNA sequences of COI and ITS1 in the ectosymbiotic bivalves (Galeommatoidea) attached to the inarticulate brachiopods: Lingula anatina and L. adamsi

Jae-Won YOO, Chang-Soo KIM, Chang-Gun LEE, Mi-Ra PARK, Kon-Tak YOON, In-Seo HWANG, Hoe-In JUNG, Jae-Sang HONG (Korea)

Empirical models for predicting gamma diversity in macrobenthic communities of Korean tidal flats

Satomi KAMIMURA, Miho SASAKI and Masami HAMAGUCHI (Japan)

Molecular identification in the intertidal gastropods Batillaria and Cerithidea

Chang-Gun LEE, Kon-Tak YOON, In-Suh HWANG, Sang-Pil YOON and Jae- Sang HONG (Korea) In-situ measurement of the removal flux of particulate organic matter by the two dominant clams (Ruditapes philippinarum and Mactra veneriformis) in Korean Tidal Flats

Frolan A. AYA and Isao KUDO (Japan)

Isotopic shifts of Japanese scallop Patinopecten yessoensis (Jay) with changes in size and culture habitat

\section{Chang-Soo KIM, Jae-Won YOO, and Jae-Sang HONG (Korea)}

Temporal pattern of colonization process of the benthic macrofauna in Seonjae-do tidal flat, Incheon, Korea

\section{Byoung-Mi CHOI and Jae-Sang HONG (Korea)}

New records of polychaetous annelids from Korea 
In-Seo HWANG, Dong-sup KIM, Jae-Won YOO, Chang-Soo KIM, Chang-Gun LEE, Kang-soon CHOI, Se-Won KIM and Jae-Sang HONG (Korea)

Intertidal macrobenthic community changes induced by prolonged and irregular tidal regime in Lake Sihwa (Gyeonggi Bay, Yellow Sea, Korea)

\section{In-Soo SEO and Jae-Sang HONG (Korea)}

Food Habits of The Asian Paddle Crab Charybdis japonica on the Jangbong Tidal Flat, Incheon, Korea

Byoung-Seol KOH, Yong-Hyun KIM, Rae-Hong JUNG, Sang-Pil YOON, Dong-Woon HWANG, Jae-Hee SONG, Yeong-Jo JO, Young-Je PARK (Korea)

Changes of Macro Benthic Fauna caused by Oil Spill in Taean Coast in the Yellow Sea

Byoung-Seol KOH, Ok-In CHOI, Yeong-Jo JO, Jae-Hee SONG, Dae-Hyun KWAN (Korea)

Human Activities Impacts on the Tidal Flats Benthic Ecosystem

\section{Chul-hwan KOH, Bong-Oh KWON, Minkyu KIM, Jong Seong KHIM (Korea)}

A measurement of microphytobenthic productivity by use of oxygen microelectrode 